\title{
Attitudes towards Science in Psychology: Relationships with Sociodemographic Characteristics among Brazilian Students and Professionals
}

\author{
Bheatrix Bienemann ${ }^{*}, 1$ \\ Orcid.org/0000-0003-4291-4612 \\ Bruno Figueiredo Damásio ${ }^{2}$ \\ Orcid.org/0000-0002-1150-092X
}

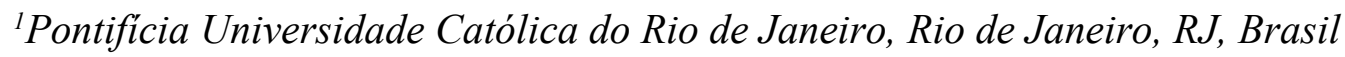

${ }^{2}$ Universidade Federal do Rio de Janeiro, Rio de Janeiro, RJ, Brasil

\begin{abstract}
The scientific method is indispensable for the consolidation of evidence-based Psychology. However, Psychology is a discipline permeated by doubts about its scientific nature, and there are resistances to the scientific method by its students and professionals. The aim of this study was to verify relations between Attitude towards Science in Psychology's scores (ATSP) and sociodemographic characteristics. Participants were 611 people, students or professionals of Psychology, from all regions of Brazil, with 18 to 75 years, $64.2 \%$ women. Participants answered a sociodemographic questionnaire and the Attitude towards Science in Psychology Scale. Men presented ATSP more favorable than women, as did students from private universities compared to public universities and people who work in relation to those who do not work. Rio de Janeiro presented lower rates of ATSP compared to other states in the South and Southeast. The results promote preliminary findings of variables involved in the difficulty of constructing a scientific psychology in Brazil.
\end{abstract}

Keywords: Attitude towards science, epistemology, scientific method, formation.

\section{Atitudes em Relação à Ciência na Psicologia: Relações com Características Sociodemográficas entre Estudantes e Profissionais Brasileiros}

\section{Resumo}

O método científico é importante para a consolidação da Psicologia baseada em evidências. Entretanto, a Psicologia é uma disciplina permeada por dúvidas em relação à sua cientificidade, e há resistências à pesquisa científica por parte de seus estudantes e profissionais. O objetivo deste estudo foi verificar relações entre escores de atitude em relação à ciência na Psicologia (ARCP) e características sociodemográficas. Participaram 611 pessoas, estudantes ou profissionais da Psicologia, de todas as regiões brasileiras, com 18 a 75 anos, sendo 64,2\% mulheres. Os participantes responderam um questionário sociodemográfico

* Mailing address: Rua Marquês de São Vicente, 225, Gávea, Rio de Janeiro - RJ, Brazil 22430-060. E-mail: bheatrixbf@gmail.com. 
e à Escala de Atitude em Relação à Ciência na Psicologia. Homens apresentaram ARCP mais favorável do que mulheres, assim como os alunos de instituições privadas em relação aos de instituições públicas e pessoas que trabalham em relação às que não trabalham. O Rio de Janeiro apresentou menores índices de ARCP em comparação com os outros estados do Sul e Sudeste. Os resultados promovem apontamentos preliminares sobre as variáveis envolvidas na dificuldade de se construir uma Psicologia científica no Brasil.

Palavras-chave: Atitude em relação à ciência, epistemologia, método científico, formação.

\section{Actitudes en Relación a la Ciencia en la Psicología: Relaciones con Características Sociodemográficas entre Estudiantes y Profesionales Brasileños}

\section{Resúmen}

El método científico es importante para la consolidación de la Psicología basada en evidencias. Sin embargo, la Psicología es una disciplina permeada por dudas en relación a su cientificidad, existiendo resistencia en el uso del la investigación científica por parte de estudiantes y profesionales del área. El objetivo de este estudio fue verificar relaciones entre las puntuaciones de actitud en relación a la ciencia en la Psicología (ARCP) y características sociodemográficas. Participaron 611 personas, entre estudiantes o profesionales de Psicología de todas las regiones brasileñas, de 18 a 75 años, siendo 64,2\% mujeres. Los participantes respondieron un cuestionario sociodemográfico y la Escala de Actitud en relación a la Ciencia en Psicología. Los hombres presentaron ARCP más favorable que las mujeres, así como los alumnos de instituciones privadas en relación a los de instituciones públicas y personas que trabajan en relación a las que no trabajan. Río de Janeiro presentó menores índices de ARCP en comparación con los otros estados del Sur y Sudeste. Los resultados promueven apuntes preliminares sobre las variables involucradas en la dificultad de construir una Psicología científica en Brasil.

Palabras clave: Actitud hacia la ciencia, epistemología, método científico, formación.

Since being recognized in 1962 , what it means to be a psychologist, as a profession, has been growing rapidly and continuously, as well as its involvement in a wide variety of areas. Currently, there are more than 305 thousand psychologists registered in Brazil with the Federal Council of Psychology (2018). The disordered growth of Psychology programs in Brazil (Lisboa \& Barbosa, 2009) has resulted in the programs being mainly concentrated in the private network, through the opening of an abundance of positions in relatively inexpensive programs, which has consequently resulted in a diminished quality of the teaching offered (Catani \& de Oliveira, 2002; de Oliveira \& Dourado, 2003). Data retrieved from the online database of Ministry of Education - MEC, 2018, (http://emec.mec.gov.br) indicates that there are 818 existing Higher Education Institutions (IESs) offering Psychology programs in the country, of which about $730(89 \%)$ are institutions that offer paid programs. Public universities also followed the same logic of expansion, while attending to political initiatives to reduce expenses, expansion of the teacherstudent relationship and to decrease the cost per student in federal universities (de Oliveira $\&$ Dourado, 2003). In addition to the current gap between the number of master's degree and doctoral graduates and the demand for teachers to meet the expansion of Psychology programs (Coordination for the Improvement of Higher Education Personnel [CAPES], 2013), such factors have a negative impact on the teaching offered in Psychology programs (Lisboa \& Barbosa, 2009), resulting in a scenario of low 
levels of training in terms of theory and skills, for the pursuit of scientific evidence on the behalf of trained professionals (Cruz, 2016).

Psychology is an area marked by vast plurality, composed ofdifferent schools of thought from distinct origins, different paradigms, as well as ontological and epistemological conflicts that have not yet been overcome (Hayes, Long, Levin, \& Follette, 2013). These differences are even expressed in respect to the object of study of Psychology itself (Ferreira, 2008), and some schools of thought believe that this object is not subject to scientific investigation - which confers a marked methodological difference between these and the others. Among the schools of thought in psychology, there are still those that are based on postmodernist (e.g. Lyotard, 1979) and poststructuralist assumptions (e.g. Derrida, 1987/2003; Foucault, 1961/2004) - question the very validity of science as a method of acquiring knowledge (Castañon, 2004b), and those that propose a revision or rationalization of the methods of science, in the mold of the new ideas on the Philosophy of Science (e.g. Feyerabend, 1975; Latour, 1987/2011; Kuhn, 1970). Such a theoretical and methodological plurality is associated with possible gaps in the scientific training of the psychologist (Lilienfeld, 2010) and constitutes a challenging scenario for the consolidation of psychology as a science.

Much of this diversity seems to stem from a confusion related to the very definition of what science is and whether it can be applied to psychological aspects (Gallo \& Barlow, 2012; Lilienfeld, 2010). This is because the term science has meanings ranging from being a simple equivalent to knowledge to a specific method of obtaining knowledge that involves empirical and logical principles (2016). The definition of science in this study is in alignment with this second direction, that is, the scientific method a method of acquiring knowledge with specific requirements. Although such requirements are often rationalized by the current authors of Psychology (Lilienfeld, 2010), the discussion of the scientific logic for the Philosophy of Science in modern times began to take place mainly from the hypothetical-deductive paradigm (hd, Popper, 1959/2004), since the inductive paradigm, characteristic of the positivist scientific method has come to be recognized as being insufficient for testing hypotheses (Andersen \& Hepburn, 2015). Although certain philosophers of science question the h-d method, especially with regard to the advancement of knowledge (e.g. Kuhn, 1970), there seems to be no other methodological logic proposed for acquiring scientific knowledge, and a good part of the problems posed by these philosophers have been solved without abandoning h-d logic (e.g. Lakatos, 1978). Thus, in line with such a philosophical discussion, the scientific method discussed in this study is the h-d method which can be summarized, in general terms, in the following steps: (1) formulation of testable hypotheses derived from questioning made from observations, (2) predictions, (3) experiments, (4) rejection or not of hypotheses which, if not refuted, continue being considered as the most probable explanations (Popper, 1959/2004).

Considering the importance of the scientific method for the maintenance of evidence-based psychological practice (Stanovich, 2013), we assume that it is necessary to investigate how professionals and students in the field value science and are committed to linking it to their practices. Thus, the objective of this study was to assess to what degree students and professionals of Psychology are favorable to the scientific practice in the area, by measuring their attitudes in relation to the theme. Although there is no consensus in the literature on whether attitudes are reliable predictors of behavior (Fishbein \& Ajzen, 2011), it is known that they play an important role in relation to one's conduct when faced with a certain theme or object, indirectly influencing behavior through perception and creation of goals (Kruglanski et al., 2015). In addition, the scale used in this study has a clear predisposition towards the behavioral component in relation to the willingness of students and professionals to construct a scientific form of psychology (Bienemann \& Damásio, 2017). 
We sought to verify whether there is a relationship between the attitude towards science in Psychology (ATSP) and the age of participants, gender, state and region of residence, educational level, religiosity and work. During the literature review phase for the preparation of this study, we did not find previous studies that sought to measure ATSP in students and professionals from the area. Thus, there are no specific hypotheses on how the relationship between sociodemographic characteristics and ATSP will interact.

Table 1

Socio-Demographic Characteristics of the Sample

\begin{tabular}{|c|c|c|c|c|c|c|}
\hline \multirow{3}{*}{ Age } & \multicolumn{2}{|c|}{ Total } & \multicolumn{2}{|c|}{ Men } & \multicolumn{2}{|c|}{ Women } \\
\hline & $M$ & $S D$ & $M$ & $S D$ & $M$ & $S D$ \\
\hline & 27.01 & 8.09 & 25.74 & 6.35 & 27.72 & 8.84 \\
\hline Age in categories & $N$ & $\%$ & $n$ & $\%$ & $n$ & $\%$ \\
\hline $18-25$ age & 343 & 56.1 & 133 & 53.6 & 210 & 53.6 \\
\hline $26-35$ age & 191 & 31.3 & 69 & 31.1 & 122 & 31.1 \\
\hline $36-55$ age & 70 & 11.5 & 16 & 13.8 & 54 & 13.8 \\
\hline $56-65$ age & 7 & 1.1 & 1 & 1.5 & 6 & 1.5 \\
\hline \multicolumn{7}{|l|}{ Brazil's Zone } \\
\hline Southeast & 330 & 54 & 113 & 51.6 & 217 & 55.4 \\
\hline South & 149 & 24.4 & 49 & 22.4 & 100 & 25.5 \\
\hline Northeast & 94 & 15.4 & 39 & 17.8 & 55 & 14 \\
\hline Midwest & 26 & 4.3 & 14 & 6.4 & 12 & 3.1 \\
\hline North & 12 & 2 & 4 & 1.8 & 8 & 2 \\
\hline \multicolumn{7}{|l|}{ Scholarship } \\
\hline Undergraduate & 402 & 65.8 & 150 & 68.5 & 252 & 64.3 \\
\hline Specialization & 64 & 10.5 & 18 & 8.2 & 46 & 11.7 \\
\hline Master's degree & 73 & 11.9 & 25 & 11.4 & 48 & 12.2 \\
\hline $\mathrm{PhD}$ & 72 & 11.8 & 26 & 11.9 & 46 & 11.7 \\
\hline \multicolumn{7}{|l|}{ Religious belief } \\
\hline Yes & 347 & 56.8 & 83 & 37.9 & 264 & 67.3 \\
\hline No & 264 & 43.2 & 136 & 62.1 & 128 & 32.7 \\
\hline \multicolumn{7}{|l|}{ Civil status } \\
\hline Single & 484 & 69.4 & 175 & 79.9 & 254 & 64.8 \\
\hline Married & 105 & 15.1 & 15 & 6.8 & 74 & 18.9 \\
\hline Stable union & 64 & 9.2 & 17 & 7.8 & 31 & 7.9 \\
\hline Engaged & 21 & 3 & 8 & 3.7 & 15 & 3.8 \\
\hline Divorced & 21 & 3 & 2 & 0.9 & 16 & 4.1 \\
\hline Widower & 2 & 0.3 & 0 & 0 & 1 & 0.3 \\
\hline Civil union & 0 & 0 & 2 & 0.9 & 1 & 0.3 \\
\hline
\end{tabular}

Note. $M=$ Mean; $S D=$ Standard deviation.

\section{Method}

\section{Participants}

This study was part of a larger study on the construction and validation of the Attitude towards Science in Psychology Scale - ATSPS (EARC-P, Bienemann \& Damásio, 2017). The sample consisted of 611 people, representing students $(n=345)$ and professionals $(n=266)$ of Psychology. Regarding gender, 392 were female $(64.2 \%)$. The age profile of the sample ranged from 18 to 75 years of age $(M=27.51$ and $S D=$ 9.8). The full description of the participants can be seen in Table 1. 


\section{Instruments}

Sociodemographic Questionnaire. This questionnaire was constructed by the authors of the study with the objective being to gather sociodemographic information on the participants, such as gender, age, educational level, place of residence, type of higher education institution at which the participant studies/studied (public or private), location of training, etc.

Attitude Towards Science in Psychology Scale - ATSPS (EARC-P, Bienemann \& Damásio, 2017). This instrument is intended for professionals and students of Psychology and aims to evaluate their attitudes towards science in Psychology, that is, to what degree this public is favorable to the scientific practice in the area. The scale consists of 41 items, answered by a 5 - point Likert scale (1 - totally disagree, 5 strongly agree), and the higher the score on the scale, the more favorable the individual is to the application of science in Psychology. In the original validation study, the exploratory factor analysis clearly demonstrated a two factor structure (factor 1: Beliefs and Affections, factor 2: Personal Initiative) with factor loadings varying from 0.48 to 0.97 for Beliefs and Affections and from 0.48 to 0.98 for Personal Initiative. The alpha coefficient was 0.96 for Beliefs and Affections and 0.98 for Personal Initiative. The adjustment indices of the final version of the instrument, used in this study, were: $\mathrm{X}^{2}=1920.22 ; d f=778 ; \mathrm{X}^{2} / d f=2.47$; CFI $=0.96 ;$ TLI $=0.96 ;$ RMSEA $(90 \% \mathrm{CI})=0.069$ (0.065-0.073). Regarding the definition of the construct of this scale, the authors approached science within the Popperian perspective of the h-d method, although they did not present this definition in the body of the scale in order to avoid ideological bias among the respondents (Bienemann \& Damásio, 2017).

For purposes of understanding, the PI factor refers to behavioral dispositions related to the construction and valuation of Psychology as a science. Whereas, the BA factor, the beliefs and feelings that people have about Psychology being a scientific discipline.

\section{Data Collection Procedure and Ethical Procedures}

The data collection was performed virtually, through an online platform. The link for participation in the study was promoted in social networks and by way of e-mail distribution lists. The study questionnaire was only started upon obtaining the agreement with and acceptance of the Informed Consent Form (ICF), which is on the first page of the study. The privacy of the participants, as well as the secrecy and confidentiality of the data were guaranteed. In addition, the participants were informed that they could abandon the study at any time, without incurring any kind of loss or negative consequence. The study was approved by the research ethics committee of the Universidade Federal do Rio de Janeiro, based on the guidelines of Resolution 510/2016, which regulates research with human beings in the social and human sciences (Protocol number CAAE 38318314.2.0000.5582).

\section{Procedure for Data Analysis}

Initially, Pearson correlations were calculated between age and ATSPS scores. Then, Student's $t$-tests were then performed to compare the ATSPS scores in relation to gender, religiosity (presence or absence), type of HEIs for the students attending higher education (public or private) and between those working not working. We also compared the scores between the different regions of Brazil and those states that presented $n$ above 30 participants. As a methodological decision, it was chosen to exclude states for which the participation was less than 30 , since results with small and unrepresentative samples of the population tend to be unreliable (Tabachnick \& Fidell, 2014).

We attempted to investigate, by applying a variance analysis (ANOVA), whether the ATSPS scores varied among people with different levels of education (Level 1 = up to "Higher Education Completed ", Level 2 = up to "Specialization Completed", Level 3 = up to "Master's Degree 
Completed" and Level $4=$ up to " Doctorate Completed").

For all variance analyses, re-sampling procedures were implemented (bootstrapping, 1000 re-samples, with a Confidence interval of $99 \%$ ), with the objective being to present greater reliability in the results, by correcting possible deviations from the normality of the sample, and presenting a $99 \%$ Confidence interval for the mean differences (Haukoos \& Lewis, 2005). The size of the effect of the ANOVA was calculated using eta-squared $\left(h^{2}\right)$. The size of the effect for the peer-to-peer (post-hoc) comparisons was calculated using Cohen's $d$.

\section{Results}

A one-way ANOVA was performed with the objective being to compare the ATSPS scores (Personal Initiative - PI, and Beliefs and Affections, BA) for people with different levels of education (Level 1 = up to "Higher Education Completed ", Level 2 = up to "Specialization Completed", Level 3 = up to "Master's Degree Completed" and Level $4=$ up to "Doctorate Completed"). Both the PI factor and the BA factor presented statistically significant differences between the different levels of education [PI factor: $F(3,607)=20.05 ; p<.01 ; \eta^{2}=0.09$; Factor BA: $\left.F(3.607)=17.35 ; p<.01 ; \eta^{2}=0.08\right]$. Bonferroni's post-hoc tests demonstrated that the differences found in the PI factor are between education levels 1 and 3,1 and 4, 2 and 4, as well as 3 and 4 , and that differences in the BA factor are between levels 1 and 3, 1 and 4, as well as 2 and 4 (See Table 2).

Subsequently, we tried to investigate, through the Student's $t$ test, differences in the ATSPS scores for gender, religiosity (presence and absence of religion or spiritual belief), type of HEI (public or private) and between people who work and people who do not work (See Table 3). Significant differences were found between men and women in both the PI factor $[t(609)=-2.76 ; p<.01 ; d=0.23]$ and in the BA factor [ $t$ (609) $-2.81 p<.01 d=0.24]$. Men presented statistically higher scores than women in both factors, but the size of the effect of the differences was small in both.

Regarding the presence of religiosity or spiritual belief, a small marginal difference was found in the PI factor $[t(609)=-1.9 ; p=.058 ; d$ $=0.16]$ and a statistically significant difference in the BA factor $[t(508,286)=-2.66 ; p<.01 ; d=$ $0.22]$. People who declared they had no religion had statistically higher scores than those who claimed to have religion in both factors, although the size of the effect of the differences was small.

The Student's $t$ test was also conducted for independent samples to verify whether, among the subjects who were still enrolled in undergraduate school $(n=331)$, there were differences in the levels of attitude among participants that attended a public $(n=207)$ or private university $(n=124)$. Statistically significant differences were found in the PI Factor $[t(329)=-4.69 ; p<.01 ; d=0.53]$ with the mean effect size and in the BA factor $[t(329)=-4.76$; $p<.01 ; d=0.54]$ also with the mean effect size. Participants attending undergraduate degrees in private institutions had significantly higher scores than participants in public institutions.

In relation to work, we sought to investigate differences in ATSPS scores between those who said they worked $(n=392)$ and those who did not work $(n=317)$. There were statistically significant differences in the PI factor $[t$ (607) $=4.92 ; p<.01 ; d=0.38]$ and in the BA factor $[t$ $(607)=3.92 ; p<.01 ; d=0.32]$. In both factors, those who work were shown to have more favorable scores than those who do not work. The complete data for the comparison between groups by Student's $t$-test can be seen in Table 3 .

Pearson correlations were used to verify the relationship between the ATSPS scores and the age of the participants. Very weak positive correlations were found in both factors [PI factor: $r=0.12 ; p<.01$. Factor BA: $r=0.09 ; p<.05]$. In addition, a comparison was made using one-way ANOVA between the scores in the different states in which the participants reside. The inclusion criterion for the state in the comparison was to have $n$ above 30 participants, so that the analysis could be performed. Therefore, the comparison 
Table 2

One-Way ANOVA between ATSPS's Scores in Personal Initiative Factor and Scholarship Levels

\begin{tabular}{|c|c|c|c|c|}
\hline $\begin{array}{l}\text { ATSPS } \\
\text { PI factor }\end{array}$ & Mean $(S D)$ & $\Delta M[99 \% \mathrm{CI}]$ & Sig. & Effect size $(d)$ \\
\hline $\begin{array}{l}\text { Undergraduate } \\
\text { Specialization }\end{array}$ & $\begin{array}{l}43.30(8.25) \\
45.16(7.07)\end{array}$ & $-1.85[-4.50-1.0]$ & 0.46 & 0.23 \\
\hline $\begin{array}{l}\text { Undergraduate } \\
\text { Master's degree }\end{array}$ & $\begin{array}{l}43.30(8.25) \\
46.62(7.23)\end{array}$ & $-3.31[-5.6--0.66]$ & $0.00 *$ & 0.41 \\
\hline $\begin{array}{c}\text { Undergraduate } \\
\mathrm{PhD}\end{array}$ & $\begin{array}{l}43.30(8.25) \\
50.68(5.94)\end{array}$ & $-7.38[-9.43--4.77]$ & $0.00 *$ & 0.93 \\
\hline $\begin{array}{l}\text { Specialization } \\
\text { Master's degree }\end{array}$ & $\begin{array}{l}45.16(7.07) \\
46.62(7.23)\end{array}$ & $-1.46[-4.67-1.92]$ & 1.00 & 0.21 \\
\hline $\begin{array}{c}\text { Specialization } \\
\mathrm{PhD}\end{array}$ & $\begin{array}{l}45.16(7.07) \\
50.68(5.94)\end{array}$ & $-5.52[-8.44--2.18]$ & $0.00 *$ & 0.86 \\
\hline $\begin{array}{c}\text { Master's degree } \\
\text { PhD }\end{array}$ & $\begin{array}{l}46.62(7.23) \\
50.68(5.94)\end{array}$ & $-4.06[0.94-7.07$ & $0.01 *$ & 0.62 \\
\hline $\begin{array}{l}\text { ATSPS } \\
\text { BA factor }\end{array}$ & Mean $(S D)$ & $\Delta M[99 \% \mathrm{CI}]$ & Sig. & Effect size $(d)$ \\
\hline $\begin{array}{l}\text { Undergraduate } \\
\text { Specialization }\end{array}$ & $\begin{array}{l}115.78(21.47) \\
121.22(20.10)\end{array}$ & $-5.44[-12.38-1.37]$ & 0.31 & 0.26 \\
\hline $\begin{array}{l}\text { Undergraduate } \\
\text { Master's degree }\end{array}$ & $\begin{array}{l}115.78(21.47) \\
127.15(20.67)\end{array}$ & $-11.37[-18.44--4.09]$ & $0.00 *$ & 0.53 \\
\hline $\begin{array}{c}\text { Undergraduate } \\
\text { PhD }\end{array}$ & $\begin{array}{c}115.78(21.47) \\
132.57(16 ., 31)\end{array}$ & $-16.79[-21.69--10.67]$ & $0.00 *$ & 0.81 \\
\hline $\begin{array}{l}\text { Specialization } \\
\text { Master's degree }\end{array}$ & $\begin{array}{l}121.22(20.10) \\
127.15(20.67)\end{array}$ & $-5.93[-14.41-2.88]$ & 0.57 & 0.29 \\
\hline $\begin{array}{c}\text { Specialization } \\
\mathrm{PhD}\end{array}$ & $\begin{array}{l}121.22(20.10) \\
132.57(16.31)\end{array}$ & $-11.35[-19.18--3.78]$ & $0.01 *$ & 0.63 \\
\hline $\begin{array}{c}\text { Master's degree } \\
\text { PhD }\end{array}$ & $\begin{array}{l}127.15(20.67) \\
132.57(16.31)\end{array}$ & $-5.42[-13.36-2.81]$ & 0.69 & 0.29 \\
\hline
\end{tabular}

Note. * Statistically significant differences; $S D=$ Standard deviation; $\Delta M=$ Mean difference between groups; $\mathrm{CI}=\mathrm{Confidence}$ interval; Sig = Statistical significance; $d=$ Cohen's $d$.

was made between the following states: MG $(n$ $=45)$, PR $(n=43)$, RJ $(n=167)$, RS $(n=72)$, $\mathrm{SC}(n=34)$ and SP $(n=110)$. In the PI factor, statistically significant differences were found between the states: $[F(5,465)=6.65 ; p<.01$; $\left.\eta^{2}=0.07\right]$. Bonferroni's post-hoc tests showed that in Rio de Janeiro, there were lower scores in the ATSPS compared to all other states, except for Paraná, for which the difference was not statistically significant (Table 4).

In the BA factor, statistically significant differences were also found $[F(5,465)=7.64$; $\left.p<.01 ; \eta^{2}=0.08\right]$. Bonferroni's post-hoc tests demonstrated that Rio de Janeiro had lower scores in the ATSPS compared to all the states (see Table 5).

One-way ANOVA was also used to compare the ATSPS scores among the different regions of Brazil: North $(n=12)$, Northeast $(n=94)$, Southeast $(n=330)$, Midwest $(n=26)$ and South $(n=611)$. Statistically significant differences were found in the comparison between the regions in both the PI factor $[F(4,606)=6.03$; $\left.p<.01 ; \eta^{2}=0.04\right]$ and in the BA factor $[F(4$, 
Table 3

Student's $t$-Test of ATSPS's Scores Diferences between Groups

\begin{tabular}{|c|c|c|c|c|c|c|}
\hline ATSPS & Sex & Mean $(S D)$ & $\Delta M[99 \% \mathrm{CI}]$ & $t$ & Sig. & Effect size $(d)$ \\
\hline PI factor & $\begin{array}{c}\text { Men } \\
\text { Women }\end{array}$ & $\begin{array}{l}44.09(8.15) \\
45.97(7.97)\end{array}$ & $-1.89[-3.69--0.10]$ & -2.76 & $0.00 *$ & 0.23 \\
\hline BA factor & $\begin{array}{c}\text { Men } \\
\text { Women }\end{array}$ & $\begin{array}{l}117.87(20.86) \\
122.94(22.31)\end{array}$ & $-5.07[-9.88--0.29]$ & -2.81 & $0.00 *$ & 0.24 \\
\hline ATSPS & Religion & Mean $(S D)$ & $\Delta M[99 \% \mathrm{CI}]$ & $t$ & Sig. & Effect size $(d)$ \\
\hline PI factor & $\begin{array}{l}\text { Yes } \\
\text { No }\end{array}$ & $\begin{array}{l}44.22(7.78) \\
45.48(8.54)\end{array}$ & $-1.26[-2.98-0.41]$ & -1.9 & 0.06 & 0.16 \\
\hline BA factor & $\begin{array}{l}\text { Yes } \\
\text { No }\end{array}$ & $\begin{array}{l}117.63(19.66) \\
122.39(23.49)\end{array}$ & $-4.76[-9.6--0.4]$ & -2.66 & $0.01 *$ & 0.22 \\
\hline ATSPS & HEI & Mean $(S D)$ & $\Delta M[99 \% \mathrm{CI}]$ & $t$ & Sig. & Effect size $(d)$ \\
\hline PI factor & $\begin{array}{l}\text { Public } \\
\text { Private }\end{array}$ & $\begin{array}{l}41.55(8.51) \\
45.85(7.27)\end{array}$ & $-4.30[-6.61--2.06]$ & -4.69 & $0.00 *$ & 0.53 \\
\hline BA factor & $\begin{array}{l}\text { Public } \\
\text { Private }\end{array}$ & $\begin{array}{c}110.8(22.12) \\
122.10(18.81)\end{array}$ & $-11.31[-17.13--5.36]$ & -4.76 & $0.00 *$ & 0.54 \\
\hline ATSPS & Works? & Mean $(S D)$ & $\Delta M[99 \% \mathrm{CI}]$ & $t$ & Sig. & Effect size (d) \\
\hline PI factor & $\begin{array}{l}\text { Yes } \\
\text { No }\end{array}$ & $\begin{array}{l}46.43(7.76) \\
43.24(8.19)\end{array}$ & $3.19[1.51-4.84]$ & 4.92 & $0.00 *$ & 0.38 \\
\hline BA factor & $\begin{array}{l}\text { Yes } \\
\text { No }\end{array}$ & $\begin{array}{l}123.21(20.56) \\
116.45(21.91)\end{array}$ & $6.76[2.12-11.05]$ & 3.92 & $0.00 *$ & 0.32 \\
\hline
\end{tabular}

Note. * Statistically significant differences; $S D=$ Standard deviation; $\Delta M=$ Mean difference between groups; $\mathrm{CI}=\mathrm{Confidence}$ interval; Sig = Statistical significance; $d=$ Cohen's $d$.

606) $\left.=6.44 ; p<.01 ; \eta^{2}=0.04\right]$. As Bonferroni's post-hoc tests demonstrated, the Southeast presented significantly lower levels in the scores for the South and Mid-West in the two factors of the ATSPS, while the other states did not have statistically significant differences (Table 6 for the PI factor and Table 7 for the BA factor).

\section{Discussion}

Comparison of the ATSPS scores with the participants' different levels of education revealed that the individuals with a doctorate have higher scores than the other participants, which shows levels more favorable to the scientific practice in Psychology for this group.
In the PI factor, this difference was absolute the doctoral students and $\mathrm{PhDs}$ in Psychology presented significantly higher scores than all the other categories. An important fact that may have contributed to these differences is that people who undertake a doctorate program are presumably more involved in scientific research in psychology than, for example, undergraduates, who may be involved with a variety of activities within the Psychology program that do not involve the scientific method. Thus, the doctorate program itself may have acted as a filter per se, for a favorable opinion towards science. This is made even more explicit by the differences that have been most evident in the factor that concerns the disposition for a scientific process 
Table 4

One-Way ANOVA between ATSPS's Scores in Personal Initiative Factor and Residence State

\begin{tabular}{|c|c|c|c|c|}
\hline Brazilian State & Mean $(S D)$ & $\Delta M[99 \% \mathrm{CI}]$ & Sig. & Effect size $(d)$ \\
\hline $\begin{array}{l}\text { MG } \\
\text { PR }\end{array}$ & $\begin{array}{l}46.36(6.84) \\
45.33(5.69)\end{array}$ & $1.03[-2.79-4.23]$ & 1.00 & 0.17 \\
\hline $\begin{array}{l}\text { MG } \\
\text { RJ }\end{array}$ & $\begin{array}{l}46.36(6.84) \\
41.55(8.87)\end{array}$ & $4.80[1.28-7.81]$ & $0.00 *$ & 0.57 \\
\hline $\begin{array}{l}\text { MG } \\
\text { RS }\end{array}$ & $\begin{array}{l}46.36(6.84) \\
46.68(8.56)\end{array}$ & $-0.32[-3.97-3.76]$ & 1.00 & 0.04 \\
\hline $\begin{array}{l}\text { MG } \\
\text { SC }\end{array}$ & $\begin{array}{l}46.36(6.84) \\
46.76(6.88)\end{array}$ & $-0.41[-4.71-3.44]$ & 1.00 & 0.06 \\
\hline $\begin{array}{l}\text { MG } \\
\text { SP }\end{array}$ & $\begin{array}{l}46.36(6.84) \\
45.06(8.12)\end{array}$ & $1.29[-1.99-4.53]$ & 1.00 & 0.17 \\
\hline $\begin{array}{l}\text { PR } \\
\text { RJ }\end{array}$ & $\begin{array}{l}45.33(5.69) \\
41.55(8.87)\end{array}$ & $3.77[0.8-6.52]$ & 0.1 & 0.46 \\
\hline $\begin{array}{l}\text { PR } \\
\text { RS }\end{array}$ & $\begin{array}{l}45.33(5.69) \\
46.68(8.56)\end{array}$ & $-1.35[-5.04-2.22]$ & 1.00 & 0.18 \\
\hline $\begin{array}{l}\text { PR } \\
\text { SC }\end{array}$ & $\begin{array}{l}45.33(5.69) \\
46.76(6.88)\end{array}$ & $-1.44[-5.34-1.84]$ & 1.00 & 0.23 \\
\hline $\begin{array}{l}\text { PR } \\
\text { SP }\end{array}$ & $\begin{array}{l}45.33(5.69) \\
45.06(8.12)\end{array}$ & $0.26[-2.43-3.31]$ & 1.00 & 0.04 \\
\hline $\begin{array}{l}\text { RJ } \\
\text { RS }\end{array}$ & $\begin{array}{l}41.55(8.87) \\
46.68(8.56)\end{array}$ & $-5.13[-8.35--1.59]$ & $0.00^{*}$ & 0.59 \\
\hline $\begin{array}{l}\mathrm{RJ} \\
\mathrm{SC}\end{array}$ & $\begin{array}{l}41.55(8.87) \\
46.76(6.88)\end{array}$ & $-5.21[-8.67--1.69]$ & $0.01 *$ & 0.61 \\
\hline $\begin{array}{l}\text { RJ } \\
\text { SP }\end{array}$ & $\begin{array}{l}41.55(8.87) \\
45.06(8.12)\end{array}$ & $-3.51[-6.29--0.43]$ & $0.00^{*}$ & 0.41 \\
\hline $\begin{array}{l}\mathrm{RS} \\
\mathrm{SC}\end{array}$ & $\begin{array}{l}46.68(8.56) \\
46.76(6.88)\end{array}$ & $-0.08[-4.41-4.22]$ & 1.00 & 0.01 \\
\hline $\begin{array}{l}\mathrm{RS} \\
\mathrm{SP}\end{array}$ & $\begin{array}{l}46.68(8.56) \\
45.06(8.12)\end{array}$ & $1.62[-2.13-4.76]$ & 1.00 & 0.20 \\
\hline
\end{tabular}

Note. $*$ Statistically significant differences; $S D=$ Standard deviation; $\Delta M=$ Mean difference between groups; $\mathrm{CI}=\mathrm{Confidence}$ interval; Sig = Statistical significance; $d=$ Cohen's $d$.

within Psychology (PI). As in the PI factor, in the BA factor, the differences found also show higher rates in the ATSPS for higher levels of education, with the largest difference being found among those with Graduate degrees and those with up to a Doctorate - while also showing a greater affective and cognitive favorability on the part of those who have a doctorate in relation to those with lower levels of education.
In the comparison related to the gender of the participants there was a statistically significant difference, however, with small effect size in both factors. This shows that there is little difference between men and women in regard to their affects and beliefs related to the importance of science in psychology and willingness to contribute to the construction of scientific psychology. This difference may be an influence 
Table 5

One-Way ANOVA between ATSPS's Scores in Beliefs and Affections Factor and Residence State

\begin{tabular}{|c|c|c|c|c|}
\hline Brazilian State & Mean $(S D)$ & $\Delta M[99 \% \mathrm{CI}]$ & Sig & Effect size $(d)$ \\
\hline $\begin{array}{l}\text { MG } \\
\text { PR }\end{array}$ & $\begin{array}{l}123.80(21.68) \\
122.67(20.23)\end{array}$ & $1.13[-10.29-13.10]$ & 1.00 & 0.05 \\
\hline $\begin{array}{c}\mathrm{MG} \\
\mathrm{RJ}\end{array}$ & $\begin{array}{l}123.80(21.68) \\
110.55(22.75)\end{array}$ & $13.25[2.64-23.31]$ & $0.00 *$ & 0.59 \\
\hline $\begin{array}{c}\mathrm{MG} \\
\mathrm{RS}\end{array}$ & $\begin{array}{l}123.80(21.68) \\
122.04(21.29)\end{array}$ & $1.76[-11.02-12.84]$ & 1.00 & 0.08 \\
\hline $\begin{array}{l}\mathrm{MG} \\
\mathrm{SC}\end{array}$ & $\begin{array}{l}123.80(21.68) \\
128.79(17.80)\end{array}$ & $-4.99[-17.32-6.54]$ & 1.00 & 0.25 \\
\hline $\begin{array}{c}\text { MG } \\
\text { SP }\end{array}$ & $\begin{array}{l}123.80(21.68) \\
120.12(20.23)\end{array}$ & $3.68[-7.62-12.24]$ & 1.00 & 0.18 \\
\hline $\begin{array}{l}\text { PR } \\
\text { RJ }\end{array}$ & $\begin{array}{l}122.67(20.23) \\
110.55(22.75)\end{array}$ & $12.12[1.74-21.34]$ & $0.01 *$ & 0.55 \\
\hline $\begin{array}{l}\text { PR } \\
\text { RS }\end{array}$ & $\begin{array}{l}122.67(20.23) \\
122.04(21.29)\end{array}$ & $0.63[-10.69-10.7]$ & 1.00 & 0.03 \\
\hline $\begin{array}{l}\mathrm{PR} \\
\mathrm{SC}\end{array}$ & $\begin{array}{l}122.67(20.23) \\
128.79(17.80)\end{array}$ & $-6.12[-16.44-4.91]$ & 1.00 & 0.32 \\
\hline $\begin{array}{l}\text { PR } \\
\text { SP }\end{array}$ & $\begin{array}{l}122.67(20.23) \\
120.12(20.23)\end{array}$ & $2.56[-7.84-11.28]$ & 1.00 & 0.13 \\
\hline $\begin{array}{l}\mathrm{RJ} \\
\mathrm{RS}\end{array}$ & $\begin{array}{l}110.55(22.75) \\
122.04(21.29)\end{array}$ & $-11.49[-18.92--3.17]$ & $0.00 *$ & 0.52 \\
\hline $\begin{array}{l}\mathrm{RJ} \\
\mathrm{SC}\end{array}$ & $\begin{array}{l}110.55(22.75) \\
128.79(17.80)\end{array}$ & $-18.24[-27.04--8.77]$ & $0.00 *$ & 0.83 \\
\hline $\begin{array}{l}\mathrm{RJ} \\
\mathrm{SP}\end{array}$ & $\begin{array}{l}110.55(22.75) \\
120.12(20.23)\end{array}$ & $-9.57[-16.36--2.12]$ & $0.00 *$ & 0.44 \\
\hline $\begin{array}{l}\mathrm{RS} \\
\mathrm{SC}\end{array}$ & $\begin{array}{l}122.04(21.29) \\
128.79(17.80)\end{array}$ & $-6.75[-17.44-2.80]$ & 1.00 & 0.34 \\
\hline $\begin{array}{l}\text { RS } \\
\text { SP }\end{array}$ & $\begin{array}{l}122.04(21.29) \\
120.12(20.23)\end{array}$ & $1.92[-8.04-9.21]$ & 1.00 & 0.09 \\
\hline
\end{tabular}

Note. * Statistically significant differences; $S D=$ Standard deviation; $\Delta M=$ Mean difference between groups; $\mathrm{CI}=\mathrm{Confidence}$ interval; Sig = Statistical significance; $d=$ Cohen's $d$.

of the already confirmed greater tendency of the male to engage and enjoy science in general (Reuben, Sapienza, \& Zingales, 2014; Smith, Pasero, \& McKenna, 2014), since men at an early stage, receive more social encouragement than women to pursue a scientific career, and that there are still stereotypes that hinder the consolidation of women's scientific careers (Reuben et al., 2014). It is important to note, however, that the small effect size demonstrates practical results of little significance. This may be related to the fact that, in Brazil, Psychology is a program mostly attended by women (Federal Council of Psychology, 2018).

A small difference was also found with regard to religion. Participants who did not have a religion or spiritual belief had scores that were slightly smaller than those that consider 
Table 6

One-Way ANOVA between ATSPS's Scores in Personal Initiative Factor and Brazilian's Zone

\begin{tabular}{|c|c|c|c|c|}
\hline Zone & Mean $(S D)$ & $\Delta M[99 \% \mathrm{CI}]$ & Sig. & Effect size $(d)$ \\
\hline $\begin{array}{c}\text { North } \\
\text { Northeast }\end{array}$ & $\begin{array}{l}49.83(3.13) \\
44.85(7.62)\end{array}$ & $4.98[1.54-7.90]$ & 0.43 & 0.69 \\
\hline $\begin{array}{c}\text { North } \\
\text { Southeast }\end{array}$ & $\begin{array}{l}49.83(3.13) \\
43.55(8.56)\end{array}$ & $6.28[3.51-9.08]$ & 0.08 & 0.75 \\
\hline $\begin{array}{l}\text { North } \\
\text { Midwest }\end{array}$ & $\begin{array}{l}49.83(3.13) \\
48.65(6.38)\end{array}$ & $1.18[-2.52-5.63]$ & 1.00 & 0.22 \\
\hline $\begin{array}{l}\text { North } \\
\text { South }\end{array}$ & $\begin{array}{l}49.83(3.13) \\
46.31(7.43)\end{array}$ & $3.52[0.9-6.46]$ & 1.00 & 0.49 \\
\hline $\begin{array}{l}\text { Northeast } \\
\text { Southeast }\end{array}$ & $\begin{array}{l}44.85(7.62) \\
43.55(8.56)\end{array}$ & $1.30[-1.06-3.63]$ & 1.00 & 0.16 \\
\hline $\begin{array}{l}\text { Northeast } \\
\text { Midwest }\end{array}$ & $\begin{array}{l}44.85(7.62) \\
48.65(6.38)\end{array}$ & $-3.80[-7.56-0.12]$ & 0.32 & 0.52 \\
\hline $\begin{array}{l}\text { Northeast } \\
\text { South }\end{array}$ & $\begin{array}{l}44.85(7.62) \\
46.31(7.43)\end{array}$ & $-1.46[-4.01-1.23]$ & 1.00 & 0.19 \\
\hline $\begin{array}{l}\text { Southeast } \\
\text { Midwest }\end{array}$ & $\begin{array}{l}43.55(8.56) \\
48.65(6.38)\end{array}$ & $-5.10[-8.49--1.54]$ & $0.02 * *$ & 0.61 \\
\hline $\begin{array}{l}\text { Southeast } \\
\text { South }\end{array}$ & $\begin{array}{l}43.55(8.56) \\
48.65(6.38)\end{array}$ & $-2.76[-4.74--0.79]$ & $0.00^{*}$ & 0.34 \\
\hline $\begin{array}{l}\text { Midwest } \\
\text { South }\end{array}$ & $\begin{array}{l}48.65(6.38) \\
46.31(7.43)\end{array}$ & $2.34[-1.19-5.76]$ & 1.00 & 0.32 \\
\hline
\end{tabular}

Note. * Statistically significant differences; $S D=$ Standard deviation; $\Delta M=$ Mean difference between groups; $\mathrm{CI}=\mathrm{Confidence}$ interval; Sig = Statistical significance; $d=$ Cohen's $d$.

themselves to be religious, for both factors. Also no study was found that related ATSP with religion nor any that related religion and attitude towards science in general. However, it is important to emphasize that the scientific practice necessarily has an anti-dogmatic essence. For this reason, the relationship between science and religion may have been compromised, since dogmatic ideas are among the pillars of many religions. It is necessary to recognize, however, that this supposed incompatibility between science and religion has a historical nature and does not necessarily have to do with something irreconcilable that is intrinsic to religion and intrinsic to science. Many of the conflicts that seem to involve science and religion from opposing perspectives throughout history were, in fact, conflicts of interest related to issues of political power, social prestige, intellectual authority, and even disputes among the different theological and scientific groups themselves (Ferngren, 2017).

Very weak positive correlations were found between age and ATSPS scores, which demonstrated that the effect of age on the participants' attitudes was negligible. Regarding the type of HEI of the participants who are still attending undergraduate courses, it has been shown that people from public universities have a moderately less favorable attitude toward science than those who study at private universities in both factors. This is the first study to compare ATSP between public and private HEIs, which explains the reason for the difference still being relatively unclear. One of the hypotheses to be raised is that private HEIs 
Table 7

One-way ANOVA between ATSPS's Scores in Beliefs and Affections Factor and Brazilian's Zone

\begin{tabular}{|c|c|c|c|c|}
\hline Zone & Mean $(S D)$ & $\Delta M[99 \% \mathrm{CI}]$ & Sig. & Effect size $(d)$ \\
\hline $\begin{array}{c}\text { North } \\
\text { Northeast }\end{array}$ & $\begin{array}{l}132.33(15.67) \\
121.63(19.41)\end{array}$ & $10.71[-2.27-23.85]$ & 0.99 & 0.57 \\
\hline $\begin{array}{c}\text { North } \\
\text { Southeast }\end{array}$ & $\begin{array}{l}132.33(15.67) \\
116.07(22.37)\end{array}$ & $16.26[3.04-28.42]$ & 0.09 & 0.74 \\
\hline $\begin{array}{l}\text { North } \\
\text { Midwest }\end{array}$ & $\begin{array}{l}132.33(15.67) \\
129.38(17.26)\end{array}$ & $2.95[-12.09-17.62]$ & 1.00 & 0.18 \\
\hline $\begin{array}{l}\text { North } \\
\text { South }\end{array}$ & $\begin{array}{l}132.33(15.67) \\
123.76(20.29)\end{array}$ & $8.57[-4.07-20.73]$ & 1.00 & 0.43 \\
\hline $\begin{array}{l}\text { Northeast } \\
\text { Southeast }\end{array}$ & $\begin{array}{l}121.63(19.41) \\
116.07(22.37)\end{array}$ & $5.59[-0.68-11.29]$ & 0.25 & 0.26 \\
\hline $\begin{array}{l}\text { Northeast } \\
\text { Midwest }\end{array}$ & $\begin{array}{l}121.63(19.41) \\
129.38(17.26)\end{array}$ & $-7.76-[-17.84-2.77]$ & 0.98 & 0.41 \\
\hline $\begin{array}{l}\text { Northeast } \\
\text { South }\end{array}$ & $\begin{array}{l}121.63(19.41) \\
123.76(20.29)\end{array}$ & $-2.14[-9.04-4.71]$ & 1.00 & 0.11 \\
\hline $\begin{array}{l}\text { Southeast } \\
\text { Midwest }\end{array}$ & $\begin{array}{l}116.07(22.37) \\
129.38(17.26)\end{array}$ & $-13.31[-22.09--3.62]$ & $0.02 *$ & 0.61 \\
\hline $\begin{array}{l}\text { Southeast } \\
\text { South }\end{array}$ & $\begin{array}{l}116.07(22.37) \\
123.76(20.29)\end{array}$ & $-7.69[-13.16--2.45]$ & $0.00^{*}$ & 0.35 \\
\hline $\begin{array}{l}\text { Midwest } \\
\text { South }\end{array}$ & $\begin{array}{l}129.38(17.26) \\
123.76(20.29)\end{array}$ & $5.62[-4.02-15.45]$ & 1.00 & 0.28 \\
\hline
\end{tabular}

Note. * Statistically significant differences; $S D=$ Standard deviation; $\Delta M=$ Mean difference between groups; $\mathrm{CI}=\mathrm{Confidence}$ interval; Sig = Statistical significance; $d=$ Cohen's $d$.

may have a curriculum that is more focused on the labor market than the public counterparts, and that these may have a tradition that is more focused on academic debate. Moreover, this data may have to do with the fact that public HEIs are possibly more involved with the critical social theories of psychology, based on postmodernist epistemology, which end up acting in a manner that is contrary to or excessively critical of the scientific practice. A curious fact related to this concerns the thesis defended by Castañon (2004a) that "the allegations and the type of postmodern academic practice have gained special force in Brazil because the resources available for empirical, descriptive or experimental research are very scarce" (Castañon, 2004a, p. 165). If this hypothesis is correct, one can draw a parallel and relate the strength of these discourses in the public HEIs also due to the fact that the resources for research promotion for such institutions are more scarce or administered more poorly than in the private HEIs due to the very financial nature of the institutions. The relationship between the level of promotion of scientific research and ATSP seems to be promising and deserves to be investigated more thoroughly.

Working participants demonstrated, in both factors of the scale, that ATSP is more favorable for those employed than those who do not work. Although it was a small difference, it is possible that those who work tend to have more to pragmatism than those who do not work or a greater appreciation of the evidence that supports their techniques. However, for the 
sake of clarity, it would be necessary to know if these people are working with Psychology or other types of work (this is usually the case for students who need to pay for their own college, for example). And even if they are working in the field of Psychology, it would be important to verify what area they are working in, since there are a number of different professions within Psychology - and some of them are more related to the value and need for scientific evidence than others.

In the comparison between places of residence, the state of Rio de Janeiro had the lowest ATSPS scores compared to all other states for both factors (except for Paraná, where there was no statistically significant difference in the PI factor). This finding may be due to the fact that Rio de Janeiro had the largest number of public HEI respondents $(n=89)$ in relation to other states, but it may also be a reflection of the state's own policies to encourage scientific research. It is known, for example, that Rio de Janeiro is currently experiencing a crisis related to research funding, expressed in the reduction of disbursements of resources to scientific projects by the Rio de Janeiro Foundation for the Support of Research (FAPERJ [Fundação de Amparo à Pesquisa do Rio de Janeiro]; Crise financeira do RJ, 2016). It is known that FAPERJ went without receiving one billion Reais from the state government in the last 19 years (Falta de repasses, 2017) and only in 2017 did it receive a mere $9.5 \%$ of the budget forecast for the year (Grandelle, 2017). Since the state of Rio de Janeiro accounts for about $25 \%$ of all research conducted in Brazil (da Silva, 2016), these cuts may be negatively impacting the scientific valuation of those in Rio de Janeiro, considering that scarce resources for research may weaken the notion of the importance of science and strengthen anti-scientific discourses (Castañon, 2004a).

Another hypothesis is that, perhaps, theoretical schools of thought that do not use the scientific method have historically been consolidating in a stronger manner in Rio de Janeiro than in other states. It is known, for example, that some of the most important pioneering names of the Brazilian psychoanalytic society were located in Rio de Janeiro (Russo, 2013). This fact, coupled with the immigration of renowned Argentine psychoanalysts to the state, resulted in an enormous proliferation of psychoanalysts and psychoanalytic societies that, especially since the 1970 s, were strongly consolidating in the region (Figueiredo, 2012). Since the nineteenth century, and still today, Rio de Janeiro's culture has been deeply marked by French thought, highlighting the immense prestige of its great intellectuals - such as Sartre, Levi-Strauss, Lacan, Deleuze, Michel Foucault, among others - in the universities of Rio de Janeiro (Penna, 1992). Many of these thinkers enlist a role of opposition and criticism to the scientific activity (Bricmont \& Sokal, 1997/2011), as well as many of the names that practically initiated Psychology in Rio de Janeiro (Penna, 1992). Such historical facts may have contributed to the existence of an anti-scientific tradition in Rio de Janeiro's Psychology - a theory that needs to be further studied.

\section{Conclusion}

This study presents potentialities and limitations. Regarding the potentialities, it allows for a greater understanding of the current panorama of the reality of scientific practice in Brazilian Psychology. With the information provided, one can begin to understand some of the variables involved in the resistance to constructing Psychology as a truly scientific discipline in Brazil, as well as to consider measures to resolve such resistance and increase the valuation of the PBE by its professionals. In addition, the results show that there are several relationships between variables and unknown variables that seem to influence the levels of ATSP, for which further studies are needed.

Regarding the limitations, it is noted that, due to this being an initial study, certain explanations regarding the findings were more along the lines of hypotheses and speculations, since there appears to be insufficient literature on certain topics. In addition, it was not possible to investigate whether the participants' education 
level and income interfere with the ATSPS scores. External academic variables that may also influence these scores, such as measures of yield coefficient (YC) and the theoretical schools of thought that the participants identify with, were also not used in this study. In addition, the level of the participants' knowledge regarding science and their understanding of what science is and how the scientific method works is also important predictors of their attitudes, which would require specific studies on such factors. We hope that future studies can be carried out, which serve to broaden the knowledge regarding the formation of ATSP as well as its impact on the various fields of Psychology.

\section{References}

Andersen, H., \& Hepburn, B. (2015). Scientific Method. In E. Zalta (Ed.), Stanford Encyclopedia of Philosophy. Retrieved from https://plato. stanford.edu/entries/scientific-method/

Bienemann, B., \& Damásio, B. F. (2017). Desenvolvimento e Validação de uma Escala de Atitude em Relação à Ciência na Psicologia. Avaliação Psicológica, 16(4), 489-497.

Bricmont, J., \& Sokal, A. (2011). Intellectual impostures. London: Profile Books. (Original work published 1997)

Castañon, G. A. (2004a). Construcionismo social: Uma crítica epistemológica. Temas em Psicologia, 12(1), 67-81. Retrieved from http:// pepsic.bvsalud.org/scielo.php?script $=$ sci_ arttext\&pid=S1413-389X2004000100008

Castañon, G. A. (2004b). Pós-modernismo e política científica na Psicologia contemporânea: Uma revisão crítica. Temas em Psicologia, 12(2), 155-167. Retrieved from http://pepsic.bvsalud. org/scielo.php?script=sci_arttext\&pid=S1413389X2004000200007\&lng=pt

Catani, A. M., \& de Oliveira, J. F. (2002). Educação superior no Brasil: Reestruturação $e$ metamorfose das universidades públicas. Petrópolis, RJ: Vozes.

Coordination for the Improvement of Higher Education Personnel. (2013). Documento de Área 2013, (1), 1-69. Retrieved from http:// www.avaliacaotriena12013.capes.gov.br/ documento-de-area-e-comissao
Crise financeira do RJ prejudica pesquisas realizadas pela Faperj. (2016, September). G1 Rio de Janeiro. Retrieved from http://g1.globo.com/ rio-de-janeiro/noticia/2016/09/crise-financeirado-rj-prejudica-pesquisas-realizadas-pelafaperj.html

Cruz, R. M. (2016). Formação científica e profissional em Psicologia. Psicologia: Ciência e Profissão, 36(1), 3-5. doi: 10.1590/1982-3703003512016

da Silva, J. L. (2016, September). Crise financeira do RJ prejudica pesquisas realizadas pela Faperj. G1 Rio de Janeiro. Retrieved from http:// g1.globo.com/rio-de-janeiro/noticia/2016/09/ crise-financeira-do-rj-prejudica-pesquisasrealizadas-pela-faperj.html

de Oliveira, J. F., \& Dourado, L. F. (2003). A reforma da educação superior e os seus desdobramentos nas universidades federais: Tópicos para um debate. Série-Estudos-Periódico do Programa de Pós-Graduação em Educação da UCDB, (16). Retrieved from http://www.serie-estudos. ucdb.br/index.php/serie-estudos/article/ view/509

Derrida, J. (2003). Psyché - Inventions de L'autre - Ii. Paris: Galilée. (Original work published 1987)

Falta de repasses põe em risco pesquisas científicas no RJ. (2017, August). R7 News. Retrieved from https://noticias.r7.com/rio-de-janeiro/falta-derepasses-poe-em-risco-pesquisas-cientificas-norj-31082017

Federal Council of Psychology. (2018). Quanto somos? A Psicologia em números. Retrieved from www2.cfp.org.br/infografico/quantos-somos/

Ferngren, G. B. (2017). Science and religion: a historical introduction. Baltimore, MD: JHU Press.

Ferreira, A. A. L. (2008). O múltiplo surgimento da Psicologia. In A. M. Jacó-Vilela, A. A. L. Ferreira, \& F. T. Portugal (Eds.), História da Psicologia: Rumos e percursos (pp. 13-46) Rio de Janeiro, RJ: Nau.

Feyerabend, P. K. (1975). Against Method. London: Verso Books.

Figueiredo, A. C. (2012). A psicanálise dos psicólogos no Rio de Janeiro dos Anos 1970. Culturas Psi, (1). Retrieved from http://ppct.caicyt.gov.ar/ index.php/culturaspsi/article/view/3890

Fishbein, M., \& Ajzen, I. (2011). Predicting and changing behavior: The reasoned action approach. London: Psychology Press. 
Foucault, M. (2004). A História da Loucura na Idade Clássica (J. C. Netto, Trans.). São Paulo, SP: Perspectiva. (Original work published 1961)

Gallo, K. P., \& Barlow, D. H. (2012). Factors Involved in Clinician Adoption and Nonadoption of Evidence-Based Interventions in Mental Health. Clinical Psychology: Science and Practice, 19(1), 93-106. doi: 10.1111/j.14682850.2012.01276.x

Grandelle, R. (2017, June). Faperj recebeu apenas $9,5 \%$ do orçamento previsto para 2017. O Globo. Retrieved from https://oglobo.globo. com/sociedade/faperj-recebeu-apenas-95-doorcamento-previsto-para-2017-21522979

Haukoos, J. S., \& Lewis, R. J. (2005). Advanced Statistics: Bootstrapping Confidence intervals for Statistics with "Difficult" Distributions. Academic Emergency Medicine, 12(4), 360-365. doi: 10.1197/j.aem.2004.11.018

Hayes, S. C., Long, D. M., Levin, M. E., \& Follette, W. C. (2013). Treatment development: Can we find a better way? Clinical Psychology Review, 33(7), 870-882. doi: 10.1016/j.cpr.2012.09.009

Knowledge. (2016). Michaelis Dicionário Brasileiro da Língua Portuguesa [Dictionary of the Portuguese language]. São Paulo, SP: Melhoramentos.

Kruglanski, A. W., Jasko, K., Chernikova, M., Milyavsky, M., Babush, M., Baldner, C., \& Pierro, A. (2015). The rocky road from attitudes to behaviors: Charting the goal systemic course of actions. Psychology Review, 122(4), 598-620. doi: 10.1037/a0039541

Kuhn, T. S. (1970). The structure of scientific revolutions (2nd ed.). Chicago, IL: University of Chicago Press.

Lakatos, I. (1978). Philosophical papers. In J. Worrall \& G. Currie (Eds.), The methodology of scientific research programmes: Vol. 1. New York: Cambridge University Press.

Latour, B. (2011). Ciência em ação (I. C. Benedetti, Trans.). São Paulo, SP: Editora da Universidade Estadual Paulista "Júlio de Mesquita Filho". (Original work published 1987)
Lilienfeld, S. O. (2010). Can psychology become a science? Personality and Individual Differences, 49(4), 281-288. doi: 10.1016/j.paid.2010.01.024

Lisboa, F., \& Barbosa, A. (2009). Formação em Psicologia no Brasil: Um perfil dos Cursos de Graduação. Psicologia Ciência e Profissão, 29(4), 718-737. doi: 10.1590/S141498932009000400006

Lyotard, J. (1979). La condition postmoderne. Paris: Lés Editions de Minuit.

Ministry of Education. (2018). Instituições de Educação Superior e Cursos Cadastrados. Retrieved from http://emec.mec.gov.br

Penna, A. G. (1992). História da psicologia no Rio de Janeiro. Rio de Janeiro, RJ: Imago.

Popper, K. R. (2004). A lógica da pesquisa cientifica (L. Hegenberg \& O. Mota, Trans.). São Paulo, SP: Cultrix. (Original work published 1959)

Reuben, E., Sapienza, P., \& Zingales, L. (2014). How stereotypes impair women's careers in science. Proceedings of the National Academy of Sciences, 111(12), 4403-4408. doi: 10.1073/ pnas. 1314788111

Russo, J. A. (2013). A difusão da psicanálise no Brasil na primeira metade do século XX - Da vanguarda modernista à rádio-novela. Estudos $e$ Pesquisas em Psicologia, 2(1), 51-61. Retrieved from http://www.e-publicacoes_teste.uerj.br/ index.php/revispsi/article/view/7704

Smith, T. J., Pasero, S. L., \& McKenna, C. M. (2014). Gender effects on student attitude toward science. Bulletin of Science, Technology \& Society, 34(1-2), 7-12. doi: 10.1177/0270467614542806

Stanovich, K. E. (2013). How to think straight about Psychology (10th ed.). New York: Pearson.

Tabachnick, B. G., \& Fidell, L. S. (2014). Using Multivariate Statistics (6th ed). New York: Pearson.

Received: 02/02/2018

$1^{\text {st }}$ revision: $24 / 07 / 2018$

Accepted: 03/09/2018

(c) B BY The Author(s), 2018. Open Access. This article is distributed under the terms of the Creative Commons Attribution 4.0 International License (http://creativecommons.org/licenses/by/4.0/), which permits unrestricted use, distribution, and reproduction in any medium, provided you give appropriate credit to the original author(s) and the source, provide a link to the Creative Commons license, and indicate if changes were made. 